\title{
RADIOCARBON CHRONOLOGY OF THE LATE PLEISTOCENE-HOLOCENE PALEOGEOGRAPHIC EVENTS IN LAKE BAIKAL REGION (SIBERIA)
}

\author{
Sergey K Krivonogov ${ }^{1} \cdot$ Hikaru Takahara ${ }^{2} \cdot$ Yaroslav V Kuzmin $^{3} \bullet$ Lyobov A Orlova ${ }^{4}$ \\ A J Timothy Jull ${ }^{5} \bullet$ Toshio Nakamura $^{6} \bullet$ Norio Miyoshi $^{7} \bullet$ Kimiyasu Kawamuro $^{8} \bullet$ \\ Elena V Bezrukova ${ }^{9}$
}

\begin{abstract}
New radiocarbon dates obtained from Late Pleistocene and Holocene deposits of the southern, eastern, and northern shores of Lake Baikal in 1995-2001 are presented, and the most important results of paleoenvironmental studies based on ${ }^{14} \mathrm{C}$ data are discussed. The following paleogeographic events were verified with the help of ${ }^{14} \mathrm{C}$ dating: 1) first Late Pleistocene glaciation (Early Zyryan); 2) Middle Zyryan interstadial; 3) loess formation during the Late Zyryan (Sartan) deglaciation; 4) warm and cold events in the Late Glacial; and 5) vegetation changes and forest successions during the Late Glacial and Holocene.
\end{abstract}

\section{INTRODUCTION}

The international research program being conducted in the Lake Baikal region since 1993 (Baikal Drilling Project) concerns mainly the sedimental and environmental records in the lake cores. In addition, some projects dealt with the surroundings of Lake Baikal. One of these was a joint Russian-Japanese project, "The climate and vegetation changes in the Lake Baikal area during the last 15,000 years" (1995-2001). The project's main task was to investigate bogs and small lakes around Lake Baikal in order to obtain detailed paleoenvironmental information for the Late Glacial and Holocene, and to compare these results with those from the lacustrine sediments of Lake Baikal.

The principal results of the project were recently published in a series of articles (Bezrukova et al. 1998, 2000, 2002; Kataoka et al. 2003; Krivonogov and Takahara 2003; Takahara et al. 2000, 2001). We discovered that the climate and vegetation history of the region is better represented in the bog and small lake sediments surrounding Lake Baikal, rather than in Lake Baikal itself. The reasons for this are 1) greater thickness of the Late Glacial and Holocene sediments allows higher temporal resolution of environmental reconstructions; and 2) high biogenic content of the sediments provide good possibilities for ${ }^{14} \mathrm{C}$ dating. For example, the sedimentation rate in Lake Baikal (Akademichesky Ridge) in the Holocene was about $40 \mathrm{~mm} / 1000 \mathrm{yr}$ (Kuzmin et al. 2000), and in the surrounding small lakes and bogs, it was up to $500 \mathrm{~mm} / 1000 \mathrm{yr}$ according to our research. This permits a 10 times better resolution of paleoclimatic events. In this paper, we present a series of ${ }^{14} \mathrm{C}$ dates and discuss their importance for determining the age of paleogeographic events.

\footnotetext{
${ }^{1}$ United Institute of Geology, Geophysics, and Mineralogy, Siberian Branch of the Russian Academy of Sciences, Koptyug Ave. 3, Novosibirsk 630090, Russia. Corresponding author. Email: carpos@uiggm.nsc.ru.

${ }^{2}$ Kyoto Prefectural University, 1-5 Hangi-cho, Shimogamo, Sakyo-ku, Kyoto 606-8522, Japan.

${ }^{3}$ Pacific Institute of Geography, Far Eastern Branch of the Russian Academy of Sciences, Radio St. 7, Vladivostok 690041, Russia.

${ }^{4}$ Institute of Geology, Siberian Branch of the Russian Academy of Sciences, Koptyug Ave. 3, Novosibirsk 630090, Russia. ${ }^{5}$ NSF-Arizona AMS Facility, University of Arizona, Tucson, Arizona 85721-0081, USA.

${ }^{6}$ Center for Chronological Research, Nagoya University, Chikusa, Nagoya 464-8602, Japan.

${ }^{7}$ Okayama University of Science, 1-1 Ridai-cho, Okayama 700-0005, Japan.

${ }^{8}$ Kansai Research Center, Forestry and Forest Products Research Institute, Kyoto 612-0855, Japan.

${ }^{9}$ Limnological Institute, Siberian Branch of the Russian Academy of Sciences, Ulanbatorskaya St. 3, Irkutsk 664033, Russia.
}

(C) 2004 by the Arizona Board of Regents on behalf of the University of Arizona Proceedings of the 18th International Radiocarbon Conference, edited by N Beavan Athfield and R J Sparks RADIOCARBON, Vol 46, Nr 2, 2004, p 745-754 


\section{MATERIALS AND METHODS}

The area of our investigation covers the southern, eastern, and northern shores of Lake Baikal (Figure 1). In total, 25 boreholes were drilled and a few dozen outcrops were also investigated. Boreholes and outcrops with ${ }^{14} \mathrm{C}$ dates are shown in Figure 1. Fifty-one ${ }^{14} \mathrm{C}$ dates have been generated from several boreholes and outcrops (Table 1). Some outcrops have large series of ${ }^{14} \mathrm{C}$ dates with up to 15 values. Dates mainly correspond to the last $14,000{ }^{14} \mathrm{C}$ yr (the Late Glacial and Holocene). Earlier ${ }^{14} \mathrm{C}$ dates, about 46,000-23,000 BP, were obtained from the 2 deepest boreholes, Duliha and Bolshaya Rechka.

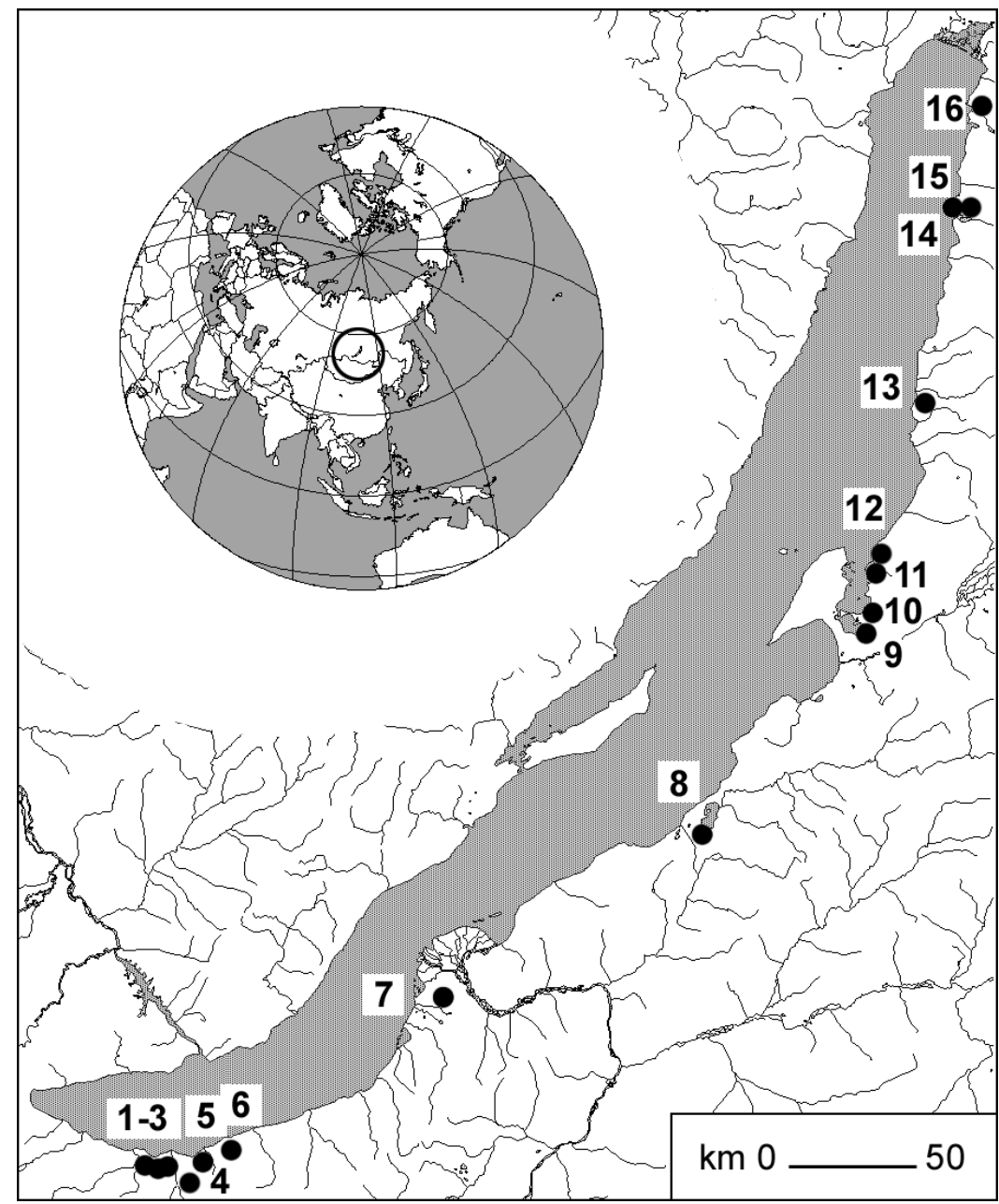

Figure 1 The area under investigation: location of the ${ }^{14} \mathrm{C}$-dated sites (numbers correspond to those in Table 1). 


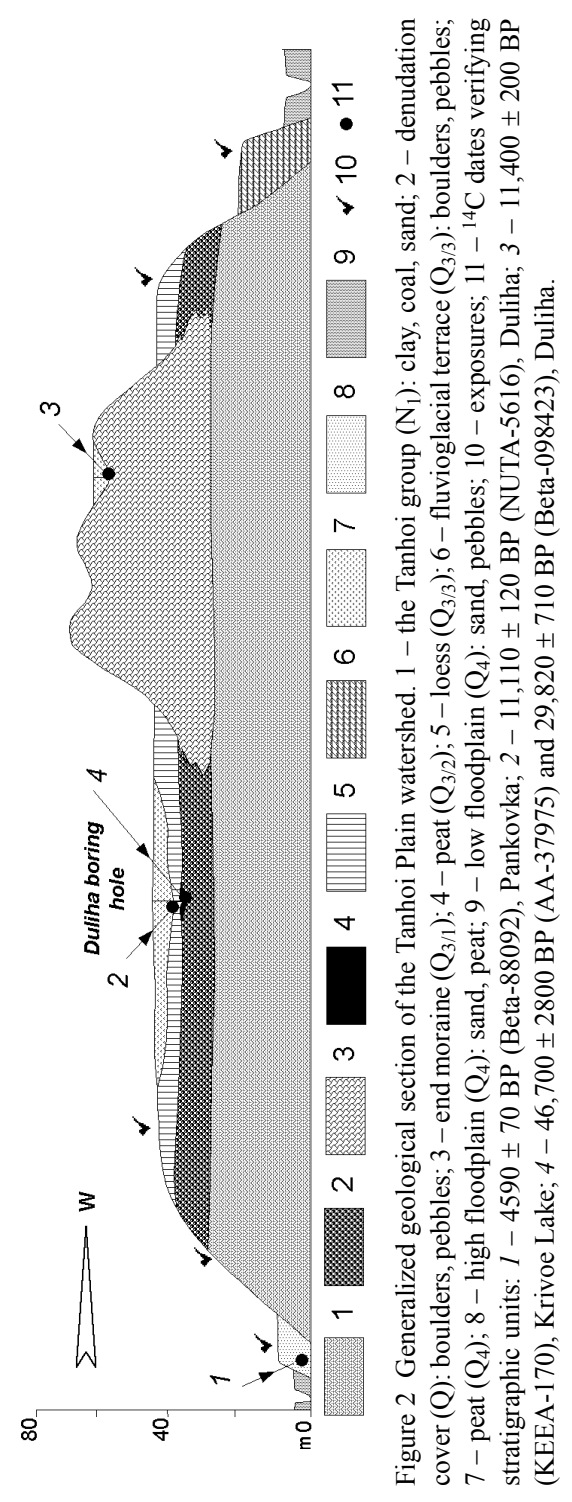


Table $1{ }^{14} \mathrm{C}$ dates obtained by the joint Russian-Japanese expedition in the Lake Baikal area.

\begin{tabular}{|c|c|c|c|c|c|}
\hline $\begin{array}{l}\text { Site name } \\
\text { and coordinates }\end{array}$ & $\begin{array}{l}\text { Type }{ }^{\mathrm{a}}, \mathrm{nr} \\
\text { from Figure } 1\end{array}$ & $\begin{array}{l}\text { Depth } \\
(\mathrm{cm})\end{array}$ & Material dated & $\begin{array}{l}\text { Lab code } \\
\text { and } \mathrm{nr}\end{array}$ & $\begin{array}{l}{ }^{14} \mathrm{C} \text { date } \\
\text { (BP) }\end{array}$ \\
\hline Pankovka River & \multirow{4}{*}{$\mathrm{S}, 1$} & $90-92$ & peat & Beta- 88090 & $1520 \pm 60$ \\
\hline \multirow{3}{*}{$51^{\circ} 28^{\prime} \mathrm{N}, 104^{\circ} 30^{\prime} \mathrm{E}$} & & $187-190$ & seeds & NUTA-4749 & $2950 \pm 60$ \\
\hline & & $302-305$ & peat & Beta- 88091 & $4000 \pm 70$ \\
\hline & & $393-398$ & peat & Beta- 88092 & $4590 \pm 70$ \\
\hline $\begin{array}{l}\text { Bolshoe bog } \\
51^{\circ} 28^{\prime} \mathrm{N}, 104^{\circ} 30^{\prime} \mathrm{E}\end{array}$ & $\mathrm{Bh}, 2$ & $238-240$ & peat & NUTA-4781 & $5330 \pm 70$ \\
\hline $\begin{array}{l}\text { Yanvarskoe bog } \\
51^{\circ} 27^{\prime} \mathrm{N}, 104^{\circ} 30^{\prime} \mathrm{E}\end{array}$ & $\mathrm{Bh}, 3$ & $268-269$ & peat & NUTA-4750 & $5680 \pm 70$ \\
\hline $\begin{array}{l}\text { Tabachnye Lakes bog } \\
51^{\circ} 29^{\prime} \mathrm{N}, 104^{\circ} 53^{\prime} \mathrm{E}\end{array}$ & Bh, 4 & 187 & plant fragment & Beta-149297 & $7070 \pm 40$ \\
\hline Krivoe Lake bog & \multirow[t]{5}{*}{$\mathrm{Bh}, 5$} & 50 & seed (Pinus sibirica) & NUTA-5444 & $1655 \pm 140$ \\
\hline \multirow[t]{4}{*}{$51^{\circ} 29^{\prime} \mathrm{N}, 104^{\circ} 50^{\prime} \mathrm{E}$} & & 210 & seed (Pinus sibirica) & NUTA-5455 & $8060 \pm 115$ \\
\hline & & $235-245$ & peat & KEEA-169 & $8520 \pm 120$ \\
\hline & & $301-304$ & seed & NUTA-5616 & $9260 \pm 120$ \\
\hline & & $341-351$ & peat & KEEA-170 & $11,400 \pm 200$ \\
\hline \multirow{8}{*}{$\begin{array}{l}\text { Duliha bog } \\
51^{\circ} 31^{\prime} \mathrm{N}, 105^{\circ} 00^{\prime} \mathrm{E}\end{array}$} & \multirow[t]{8}{*}{$\mathrm{Bh}, 6$} & $300-302$ & seeds & NUTA-5615 & $7620 \pm 115$ \\
\hline & & 399 & peat & AA-37974 & $9185 \pm 55$ \\
\hline & & $474-475$ & peat & NUTA-6038 & $11,110 \pm 120$ \\
\hline & & $612-613$ & peat & NUTA-6039 & $35,890 \pm 945$ \\
\hline & & 618 & wood & AA-37975 & $46,700 \pm 2800$ \\
\hline & & 663 & wood & AA-37976 & $35,740 \pm 850$ \\
\hline & & $679-680$ & peat & Beta- 098423 & $29,820 \pm 710$ \\
\hline & & 682 & wood & AA-37977 & $30,110 \pm 360$ \\
\hline \multirow{3}{*}{$\begin{array}{l}\text { Bolshaya Rechka bog } \\
51^{\circ} 57^{\prime} \mathrm{N}, 106^{\circ} 20^{\prime} \mathrm{E}\end{array}$} & \multirow[t]{3}{*}{$\mathrm{Bh}, 7$} & $71-73$ & wood & NUTA-5450 & $940 \pm 70$ \\
\hline & & $508-510$ & peat & Beta- 098421 & $8380 \pm 40$ \\
\hline & & $745-746$ & peat & Beta-098422 & $22,810 \pm 280$ \\
\hline $\begin{array}{l}\text { Cheremushuka bog } \\
52^{\circ} 45^{\prime} \mathrm{N}, 108^{\circ} 05^{\prime} \mathrm{E}\end{array}$ & $\mathrm{Bh}, 8$ & $366-367$ & peat & Beta-115297 & $12,100 \pm 60$ \\
\hline $\begin{array}{l}\text { Arangatui bog } \\
55^{\circ} 32^{\prime} \mathrm{N}, 109^{\circ} 08^{\prime} \mathrm{E}\end{array}$ & Bh, 9 & 474 & wood & Beta-113968 & $9400 \pm 60$ \\
\hline \multirow{6}{*}{$\begin{array}{l}\text { Chivyrkui Bay, exposure } 1^{\mathrm{b}} \\
53^{\circ} 40^{\prime} \mathrm{N}, 109^{\circ} 12^{\prime} \mathrm{E}\end{array}$} & \multirow{6}{*}{$\mathrm{S}, 10$} & $35-40$ & peat & SOAN-3803 & $1450 \pm 75$ \\
\hline & & $75-80$ & peat & SOAN-3804 & $3720 \pm 185$ \\
\hline & & $115-120$ & peat & SOAN-3805 & $3500 \pm 90$ \\
\hline & & $155-160$ & peat & SOAN-3806 & $4795 \pm 80$ \\
\hline & & $195-200$ & peat & SOAN-3807 & $5400 \pm 125$ \\
\hline & & $215-220$ & peat & SOAN-3808 & $6605 \pm 130$ \\
\hline \multirow{8}{*}{$\begin{array}{l}\text { Chivyrkui Bay, exposure } 2 \\
53^{\circ} 40^{\prime} \mathrm{N}, 109^{\circ} 12^{\prime} \mathrm{E}\end{array}$} & \multirow[t]{7}{*}{$\mathrm{S}, 10$} & $185-190^{c}$ & peat & SOAN-3809 & $5645 \pm 85$ \\
\hline & & $165-170$ & peat & SOAN-3810 & $6105 \pm 220$ \\
\hline & & $145-150$ & peat & SOAN-3811 & $7025 \pm 230$ \\
\hline & & $105-110$ & peat & SOAN-3812 & $8340 \pm 300$ \\
\hline & & $65-70$ & peat & SOAN-3813 & $9165 \pm 150$ \\
\hline & & $25-30$ & peat & SOAN-3828 & $9600 \pm 130$ \\
\hline & & $0-5$ & peat & SOAN-3829 & $10,810 \pm 150$ \\
\hline & $\mathrm{Bh}, 10$ & -25 to $-50^{\mathrm{d}}$ & peat & SOAN-3830 & $10,420 \pm 200$ \\
\hline $\begin{array}{l}\text { Chivyrkui Bay } \\
53^{\circ} 40^{\prime} \mathrm{N}, 109^{\circ} 12^{\prime} \mathrm{E}\end{array}$ & $\mathrm{Bh}, 10$ & -50 & wood & Beta-113969 & $9700 \pm 70$ \\
\hline Krohalinaya Bay bog & $\mathrm{Bh}, 11$ & 260 & peat & AA-37976 & $8550 \pm 70$ \\
\hline $53^{\circ} 46^{\prime} \mathrm{N}, 109^{\circ} 12^{\prime} \mathrm{E}$ & & 426 & peaty clay & AA-37968 & $10,980 \pm 65$ \\
\hline $\begin{array}{l}\text { Bolshoi Chivyrkui River bog } \\
53^{\circ} 49^{\prime} \mathrm{N}, 109^{\circ} 12^{\prime} \mathrm{E}\end{array}$ & Bh, 12 & $365-366$ & peat & Beta-136811 & $9650 \pm 40$ \\
\hline Duguldzeri River bog & \multirow{4}{*}{$\mathrm{Bh}, 13$} & 90 & wood & AA-37969 & $4515 \pm 40$ \\
\hline \multirow[t]{3}{*}{$54^{\circ} 27^{\prime} \mathrm{N}, 109^{\circ} 32^{\prime} \mathrm{E}$} & & 193 & seed & AA-37970 & $8020 \pm 45$ \\
\hline & & 323 & gyttja & AA-37971 & $11,295 \pm 55$ \\
\hline & & 378 & gyttja & AA-37972 & $12,950 \pm 90$ \\
\hline Tompuda bog & $\mathrm{Bh}, 14$ & $273-274$ & peat & Beta-136813 & $10,150 \pm 40$ \\
\hline $55^{\circ} 08^{\prime} \mathrm{N}, 109^{\circ} 46^{\prime} \mathrm{E}$ & & $515-516$ & gyttja & Beta-136814 & $14,090 \pm 50$ \\
\hline $\begin{array}{l}\text { Tompuda end moraine } \\
55^{\circ} 09^{\prime} \mathrm{N}, 109^{\circ} 42^{\prime} \mathrm{E}\end{array}$ & $\mathrm{S}, 15$ & & woody peat & SOAN-4266 & $9875 \pm 45$ \\
\hline $\begin{array}{l}\text { Froliha River } \\
55^{\circ} 30^{\prime} \mathrm{N}, 109^{\circ} 55^{\prime} \mathrm{E}\end{array}$ & $\mathrm{S}, 16$ & 170 & wood & AA-37973 & $8010 \pm 70$ \\
\hline
\end{tabular}

a $\mathrm{S}$ - section; $\mathrm{Bh}$ - borehole.

${ }^{b}$ For the detailed description of the sampling scheme for the sites of the Chivyrkui Bay, see Kataoka et al. (2003).

${ }^{c}$ Elevation above the Lake Baikal level.

${ }^{\mathrm{d} N e g a t i v e ~ v a l u e ~ i n d i c a t e s ~ t h e ~ s a m p l e ~ p o s i t i o n ~ b e l o w ~ t h e ~ L a k e ~ B a i k a l ~ l e v e l . ~}$ 
Palynological and plant macrofossil analyses were conducted according to standard procedures (cf. Berglund and Ralska-Jasiewiczowa 1986). The ${ }^{14} \mathrm{C}$ liquid scintillation dating (SOAN Lab, Novosibirsk, Russia; and KEEA Lab, Fukuoka, Japan) follows the general procedure for peat samples (cf. Taylor 1987; Orlova and Zykina 2003). The ${ }^{14} \mathrm{C}$ accelerator mass spectrometry (AMS) dating (Beta Lab, Miami, Florida, USA; NUTA Lab, Nagoya, Japan; and AA Lab, Tucson, Arizona, USA) was carried out according to general pretreatment and measurement protocols (cf. Tuniz et al. 1998).

\section{Paleogeographic Events in the Lake Baikal Region and Their ${ }^{14} \mathrm{C}$ Ages}

The ${ }^{14} \mathrm{C}$ dates were used as geochronological markers for stratigraphical and palynological analyses. Except for the directly dated levels, the age of paleoenvironmental boundaries and palynozones was estimated by linear interpolation between ${ }^{14} \mathrm{C}$-dated levels. The following paleogeographic events have been verified using ${ }^{14} \mathrm{C}$ dates: 1) the first Late Pleistocene glaciation (Early Zyryan, corresponding to the Early Weichselian in Europe and Early Wisconsin in North America); 2) the Middle Zyryan interstadial (corresponding to the Middle Wisconsin); 3) loess formation in the Tanhoi Plain, southern Lake Baikal shore, in the Late Zyryan (Sartan in Siberia, or Late Wisconsin in North America) deglaciation period; 4) warm and cold events in the Late Glacial; and 5) vegetation changes and forest successions during the Late Glacial and Holocene.

The glacial events in the northern, northeastern, and southern mountainous surroundings of the Lake Baikal region are recorded in broadly distributed end moraines. A wide range of ${ }^{14} \mathrm{C}$ dates generated by previous investigators was described by Back and Strecker (1998) as evidence of asymmetric and asynchronous glaciation of the Lake Baikal mountain system. Moraines of the eastern shore were created by glacier advances at more than 50,000 BP; 40,000-35,000 BP; and 26,000-13,000 BP. Careful examination of the moraine exposures revealed a lack of any organic matter, such as wood and peat, in the basal and supraglacial layers. We interpret this as an indication that temperatures were too cold during glacial times in Siberia for tree growth, and, thus, glacial tongues did not reach the tree belt in the piedmonts and did not incorporate any wood into moraines. Nevertheless, one can find wood and peat in the uppermost and distal parts of the moraine ridges. For example, the end moraine of the Tompuda Valley (Figure 1, \#15) has a ${ }^{14} \mathrm{C}$ date of 39,240 \pm 1780 BP (Mats et. al. 2001). We also found a woody peat layer in the northern part of this outcrop which was dated to $9875 \pm 45 \mathrm{BP}$ (SOAN-4266). Neither of these dates can be correlated with any significant glacial events. We suggest that the dated layers represent a drift of the post-glacial thermokarst flows which resulted from the reworking of frozen moraines or dead-ice massifs. Thus, such dates can only indicate that the glaciation itself is older; we assume it is of Early Zyryan age, older than about 39,000 BP. More obvious evidence that it is of the Early Zyryan end moraines was found on the southern shore of Lake Baikal on the Tanhoi Plane. The end moraine ridge of the Duliha River (Figure 1, \#6) is related to the surrounding sediments, as shown in Figure $2 .{ }^{14} \mathrm{C}$ dates of 46,000-30,000 BP (Table 1) were obtained for the peat that lies stratigraphically above the glacial sediments, and their age is, therefore, older than approximately 46,000 BP.

The presence of the Middle Zyryan interstadial (about 50,000-21,000 BP) in the sediments of the Lake Baikal region is still questionable. We occasionally found peat of this age at 2 sites, Duliha and Bolshaya Rechka bogs (Figure 1, \#6 and \#7). In the Duliha bog (Figure 2), the Middle Zyryan peat, dated to about 46,700-30,100 BP, lies on the layer of outwash pebbles which correlate with the end moraine ridge situated at a distance of $300 \mathrm{~m}$ from the drilling site. The peat is lens-shaped with a width of less than $10 \mathrm{~m}$ and a maximum thickness of about $0.5 \mathrm{~m}$ according to the drilling tests. We suggest that this lens occupies a small depression on the intersection of 2 melted ice wedges (tundra polygons). This allows us to explain the age differences and inversions of the ${ }^{14} \mathrm{C}$ dates (about 
$30,110 \mathrm{BP}$ on the bottom versus about $35,900 \mathrm{BP}$ and about $46,700 \mathrm{BP}$ on the top) as a result of subsidence or collapse of the peat during the long time development of the ice wedge system. Pollen analysis indicates a cool but relatively mild climate typical for the Middle Zyryan in southern Siberia (Bezrukova et al. 2000).

The loess sediments, atypical for the Lake Baikal region, were found in the western part of the Tanhoi Plain (Figure 2). The different Pleistocene sediments shown in Figure 2 are labeled as $\mathrm{Q}, \mathrm{Q}_{3}$ (Late Pleistocene), and $\mathrm{Q}_{4}$ (the Holocene). The nearest extensive loess deposits are situated on the Irkutsk-Cheremkhovo Plain, west of Irkutsk City and at least $150 \mathrm{~km} \mathrm{NW}$ of the Tanhoi Plain. The age of the Tanhoi Plain loess is estimated as Late Zyryan, older than about 11,000 BP and younger than about 30,000 BP, based on the ${ }^{14} \mathrm{C}$ ages of underlying and overlapping biogenic sediments (Table 1, Duliha borehole). Specific "wind-shadow" conditions may have permitted loess accumulation in the piedmonts of the Khamar-Daban Range and deterred erosion.

Some boreholes drilled into the lacustrine and underlying soil layers revealed ${ }^{14} \mathrm{C}$ ages of about 14,000-11,000 BP. Different events, corresponding to the warm and cool phases of the Late Glacial, were established in these boreholes using pollen data. Unfortunately, we do not have a continuous record for this period; the younger events are better represented then the older ones. Thus, the basal layer of the Duliha peat bog at a depth of about $5 \mathrm{~m}$ - characterized by pollen of deciduous trees and steppe-and-meadow grasses and dated to about 11,100 BP-corresponds to the end of the Allerød warming. In contrast, paleosol at the bottom of the Krivoe Lake bog core (Figures 1, \#5), situated in the depression on the top of the Vydrinnaya end moraine ridge, contains many Betula nana L. s.l. seeds and indicates cold conditions. Considering that the date of about 11,400 BP shows correspondence of this layer to the middle of the Allerød, this discrepancy might be evidence of a "compression" of the Older Dryas and Allerød events in the paleosol. Our only other conclusion would be that the Older Dryas vegetation survived in the Krivoe Lake depression at the Allerød. Based on these fragmentary data, we would conclude that the post-Last Glacial Maximum forest vegetation began to spread in the Lake Baikal area already at the end of the Late Glacial, and the periglacial tundra and forest tundra formations were rapidly replaced by forest formations.

Regularities in the vegetation changes and migration of the plant zones can be revealed by comparison of the data obtained at different localities. The appearance and predominance of major forest tree species since the Late Glacial, according to Bezrukova et al. (forthcoming), is shown in Figure 3. We can clearly observe the succession of larch (Larix) and spruce (Picea) assemblages by fir (Abies) and Siberian pine (Pinus sibirica) in the Boreal period of the Holocene. These formations were replaced by pine (Pinus sylvestris) in the post-Atlantic. Correlation of the pollen zones between the main localities for the last 30,000 yr is shown in Figure 4 (Takahara et. al. 2001).

\section{DISCUSSION}

The majority of the ${ }^{14} \mathrm{C}$ dates obtained are in good agreement with the sedimentation sequences and paleogeographic interpretations. However, at 2 sites we have inversions of the dates. The lowermost member of the Duliha core was accumulated in the specific conditions described above. The fluvioglacial plain of the Duliha site was developed as a tundra and forest tundra landscape over a long time, from the end of the Early Zyryan glaciation to the beginning of the Late Zyryan one. The formation and melting of ice wedges could have occurred over a prolonged period of time, resulting in mixing of the younger and older parts of the peat layer, downward migration of the organic material, and so on. An apparent inversion occurs in the upper part of the peat layer in the Chivyrkui Bay 1 outcrop: $3720 \pm 185$ BP (SOAN-3804) at a depth of 75-80 cm versus $3500 \pm 90$ BP (SOAN-3805) 

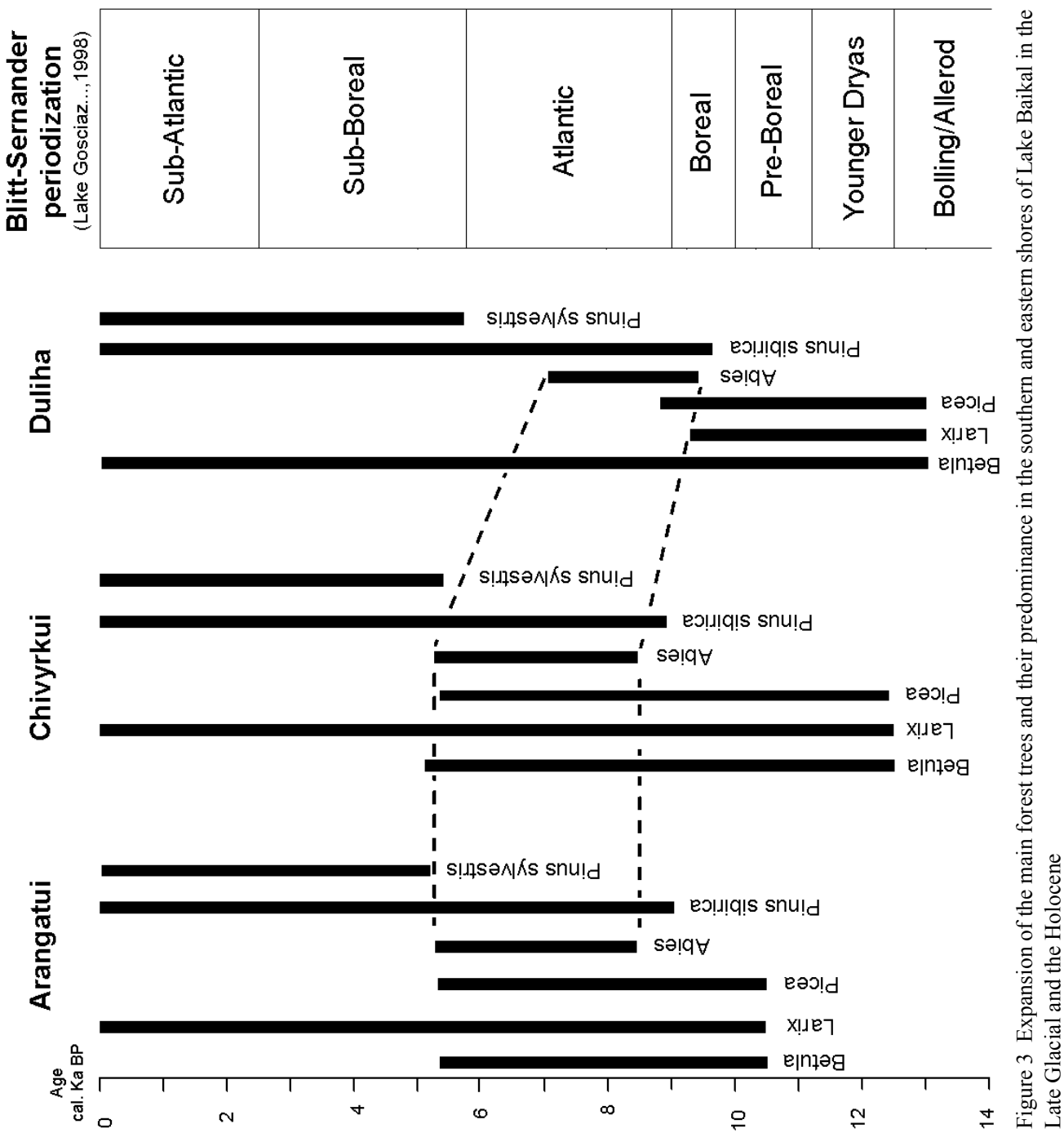


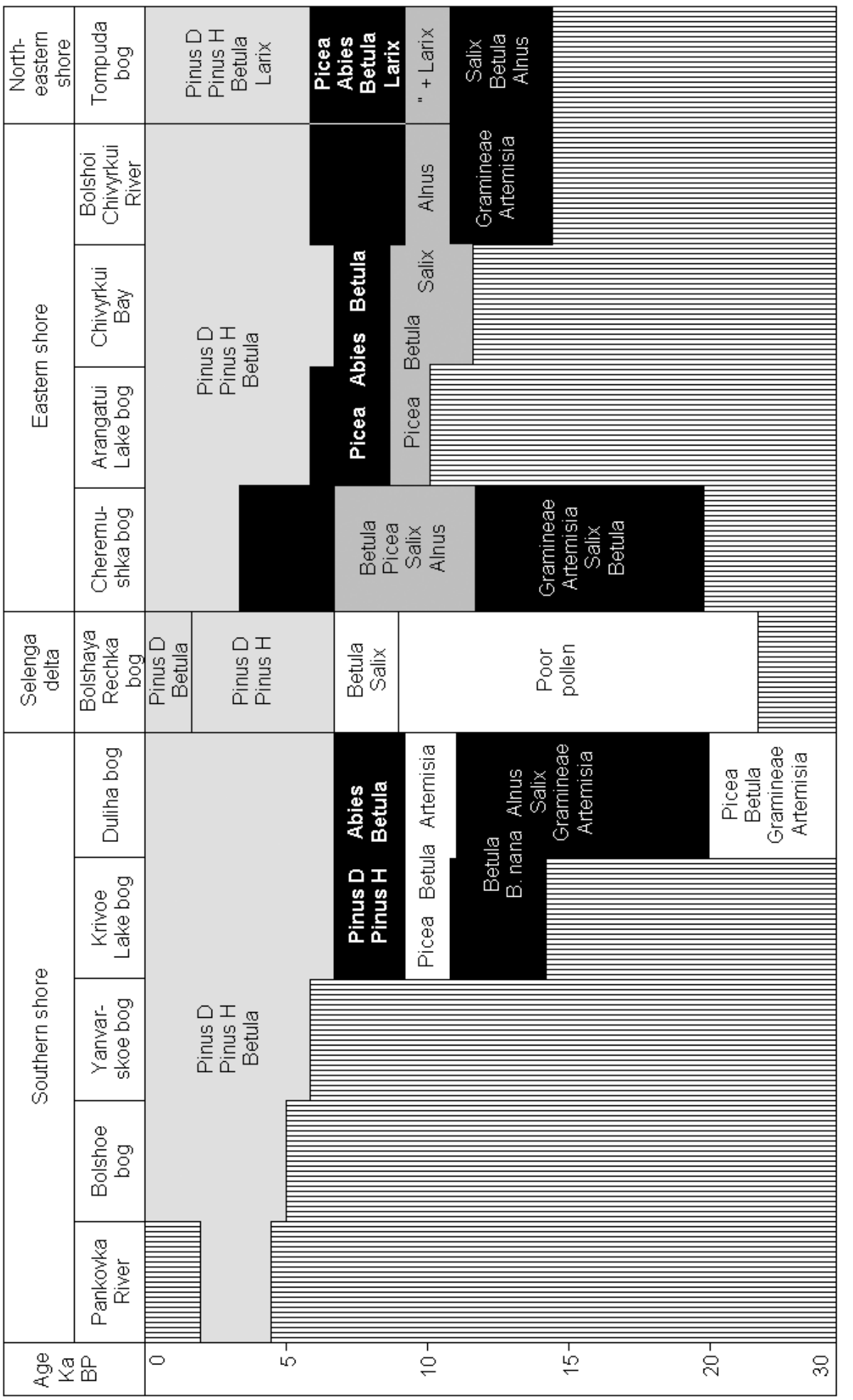

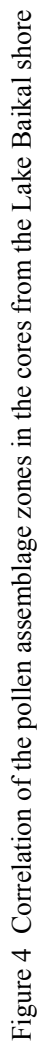


at a depth of $115-120 \mathrm{~cm}$. This bog is located in the permafrost area; erosion by the Lake Baikal waves causes melting of the exposed sediments and cracking and shifting of the peat blocks which would introduce the suggested migration. As a result, the maximum disturbance of sediments would have occurred only in the upper part of the exposure. In addition, the top of the bog is strongly influenced by the seasonal freeze-and-thaw processes up to a depth of $1 \mathrm{~m}$.

We can only suggest what may cause the large difference between ${ }^{14} \mathrm{C}$ dates from the bottom layer of the Chivyrkui outcrop, exposure 2: 10,810 $\pm 150 \mathrm{BP}$ (SOAN-3829), from peat collected at a height of $0-5 \mathrm{~cm}$ above the Lake Baikal shoreline versus 10,420 $\pm 200 \mathrm{BP}$ (SOAN-3830) from peat at a depth of $25-50 \mathrm{~cm}$ below the Lake Baikal level. Both dates were obtained by the liquid scintillation technique. The AMS date of the wood fragments found at the depth of $50 \mathrm{~cm}$ below the lake level, $9700 \pm 70$ BP (Beta-113969), showed an even larger inversion. Several factors, such as redeposition, post-depositional contamination, and differences between labs using conventional and AMS methods, may be responsible for such differences.

\section{CONCLUSION}

Paleogeographic events of the Late Glacial and Holocene recorded in the terrestrial sediments around Lake Baikal are much more detailed (to at least one order of magnitude) compared with the records from the bottom sediments of Lake Baikal. Nevertheless, the phases of significant vegetation changes observed in the palynological analysis have a minimum duration of 150-250 yr. We consider that this is a technical limitation of the resolution of the environmental reconstructions in the palynological record within the last 12,000-10,000 yr. The topmost Holocene peat layers were investigated in a wide territory, and this allowed us to make reliable spatial environmental reconstructions. As for the Late Pleistocene events, such possibilities are significantly smaller.

\section{ACKNOWLEDGEMENTS}

We are grateful to colleagues and students who participated in the drilling expeditions. Special thanks go to the staff of the radiocarbon laboratories, and to Dr S G Keates for grammar polishing. This investigation was funded by the Science and Technology Agency of Japan, the Russian Foundation for Basic Research, and the US National Science Foundation. Finally, we are grateful to Drs M McGlone and N Beavan Athfield for useful comments on the earlier version of this manuscript.

\section{REFERENCES}

Back S, Strecker MR. 1998. Asymmetric Late Pleistocene glaciations in the north Baikal basin, Baikal rift, Russia. Journal of the Geological Society of London 155:61-71.

Berglund BE, Ralska-Jasiewiczowa M, editors. 1986. Handbook of Holocene Palaeoecology and Palaeohydrology. Chichester: John Wiley. 869 p.

Bezrukova EV, Krivonogov SK, Takahara H, Abzaeva AA, Vershinin KE, Miyoshi N, Nakamura T, Morita Y, Kawamuro K, Shinomiya T, Krapivina SM. 2002. Rekonstruktsia landshaftno-klimaticheskih uslovii vostochnogo poberezhya ozera Baikal v golotsene po rezultatam kompleksnogo issledovaniya skvazhiny "Arangatui" [Reconstruction of the landscape and climate conditions of the eastern shore of the Baikal in the Holocene resulted from the complex investigation of the "Arangatui" borehole]. In: Vaganov EA, Grachev MA, Derevianko AP, Zykin VS, editors. Osnovnye zakonomernosti globalnyh i regionalnyh izmenenii klimata i prirodnoi sredy v pozdnem kainozoe Sibiri. Volume 1. Novosibirsk: Institute of Archaeology and Ethnography Press. p 36-47.

Bezrukova EV, Krivonogov SK, Takahara H, Miyoshi N, Morita Y, Takehara A, Noi X, Shinomiya T. 1998. Izmeneniya prirodnoi sredy, rastitelnosti i klimata Pribaikalya v pozdnem pleistotsene i golotsene [Changes of the environments, vegetation and climate in the Lake Baikal area during the Late Pleistocene and the Holocene]. In: Vaganov EA, Grachev MA, Derevianko AP, Zykin VS, editors. Problemy rekosntruktsii klimata i prirodnoi sredy golotsena i pleistotsena Sibiri. Novosibirsk: Institute of Archaeology and 
Ethnography Press. p 46-50.

Bezrukova EV, Krivonogov SK, Takahara H, Vershinin KE, Miyoshi N, Nakamura T, Abzaeva AA, Morita Y, Kawamuro K, Shinomiya T, Krapivina SM. 2000. Letopis pozdnepleistotsenovoi i golotsenovoi istorii yugo-vostochnogo poberezhya oz. Baikal po materialam skvazhiny Duliha [Record of the Late Pleistocene and Holocene history of south-east bank of the Lake Baikal by data from the Duliha borehole]. In: Vaganov EA, Grachev MA, Derevianko AP, Zykin VS, editors. Osnovnye zakonomernosti globalnyh i regionalnyh izmenenii klimata i prirodnoi sredy v pozdnem kainozoe Sibiri. Volume 2. Novosibirsk: Institute of Archeology and Ethnography Press. p 36-47.

Bezrukova EV, Krivonogov SK, Abzaeva AA, Vershinin KE, Orlova LA, Letunova PP, Takahara H, Miyoshi N, Nakamura T, Krapivina SM, Morita Y, Kawamuro K, Shinomiya T. Forthcoming. Landshafty i klimat Pribaikalya $\mathrm{v}$ pozdnelednikovie i golocene po rezultatam kompleksnogo issledovaniya torfyanikov na yuznom i vostochnom beregakh oz. Baikal [Landscapes and climate of the Lake Baikal area in the Late Glacial and Holocene resulted from the complex investigation of the peat sediments of the southern and eastern shores of the Lake Baikal]. Geologiya i geofizika.

Kataoka H, Takahara H, Krivonogov SK, Bezrukova EV, Orlova LA, Krapivina S, Miyoshi N, Kawamuro K. 2003. Pollen record from the Chivyrkui Bay outcrop on the eastern shore of Lake Baikal since the Late Glacial. In: Kashiwaya K, editor. Long Continental Records from Lake Baikal. Berlin: Springer-Verlag. p 207-18.

Krivonogov SK. 2003. Levels of the Baikal and Hovsgol lakes in Holocene and Pre-Holocene time. In: Kamata $\mathrm{N}$, editor. Proceedings of the International Symposium of the Kanazawa University: 21st Century COE Program. Volume 1. Kanazawa: Kanazawa University. p 123-7.

Krivonogov SK, Takahara H. 2003. Late Pleistocene and Holocene environmental changes recorded in the terrestrial sediments and landforms of Eastern Siberia and Northern Mongolia. In: Kamata N, editor. Proceedings of the International Symposium of the Kanazawa University: 21st Century COE Program. Volume 1. Kanazawa: Kanazawa University. p 30-6.

Kuzmin MI, Williams DF, Kawai T. 2000. Baikal drilling project. In: Minoura K, editor. Lake Baikal. A Mirror in Time and Space for Understanding Global Change Processes. Amsterdam: Elsevier Health Sciences. p 1-14.

Mats VD, Ufimtsev GF, Mandelbaum MM. 2001. Kainozoi Baikalskoi riftovoi vpadiny: stroenie i geologicheskaya istoriya [The Baikal Rift basin in the Cenozoic: structure and geologic history]. Novosibirsk: GEO Publ. 252 p.

Orlova LA, Zykina VS. 2003. Radiocarbon dating of buried Holocene soils in Siberia. Radiocarbon 44(1): $113-22$.

Takahara H, Krivonogov SK, Bezrukova EV, Miyoshi N, Morita Y, Nakamura T, Hase Y, Shinomiya Y, Kawamuro K. 2000. Vegetation history of the southeastern and eastern coasts of Lake Baikal from bog sediments since the Last Interstadial. In: Minoura K, editor. Lake Baikal. A Mirror in Time and Space for Understanding Global Change Processes. Amsterdam: Elsevier Health Sciences. p 108-18.

Takahara H, Ogura A, Krivonogov SK, Bezrukova EV, Miyoshi N, Hase Y, Kawamuro K, Nakamura T, Morita Y, Shichi K, Shinomiya Y, Takehara A, Uchiyama T. 2001. History of dark and light taiga forests around Lake Baikal since the Last Glacial period. In D Tomurhuu, $\mathrm{H}$ Takahara, editors. Abstracts of 2001 International Workshop for the Baikal and Hovsgol Drilling Project in Ulaanbaatar. Ulaanbaatar, Mongolia, 4-7 October 2001. Ulaanbaatar: Mongolian Academy of Sciences. p 45-6.

Taylor RE. 1987. Radiocarbon Dating: An Archaeological Perspective. Orlando, Florida: Academic Press. $212 \mathrm{p}$.

Tuniz C, Bird JR, Fink D, Herzog GF. 1998. Accelerator Mass Spectrometry: Ultrasensitive Analysis for Global Science. Boca Raton, Florida: CRC Press. 371 p. 